\title{
The range of insect dormancy responses
}

\author{
HUGH V. DANKS \\ Biological Survey of Canada (Terrestrial Arthropods), Canadian Museum of Nature, P.O. Box 3443, Station "D", Ottawa, \\ ON K1P 6P4, Canada; email: hdanks@mus-nature.ca
}

Key words. Insect, life-cycle, development, dormancy, diapause, trade-off, constraint, variation, plasticity

\begin{abstract}
Insect dormancy responses, in the broad sense of modifications of development, are examined from a general perspective. The range of responses is extraordinarily wide because environments are diverse, different taxa have different evolutionary histories, adaptations are needed for both seasonal timing and resistance to adversity, and not only development but also many other aspects of the life-cycle must be coordinated. Developmental options are illustrated by examining the wide range of ways in which development can be modified, the fact that each individual response consists of several components, and the different potential durations of the life-cycle. The concepts of alternative life-cycle pathways (chosen according to current and likely future environmental conditions) and of active and passive default responses are treated. Also introduced are aspects of variation and trade-offs.

Some general conclusions that help in understanding dormancy responses emerge from such an examination. Many options are available (cf. Table 1). The nature of the habitat, especially its predictability, determines the potential effectiveness of many of the developmental options. Any particular set of responses reflects evolutionary history and hence depends on past as well as current environments. It is not necessarily obvious what kinds of selection, especially requirements for timing versus resistance to adversity, explain a particular life cycle. Life-cycle pathways have multiple components, so that components cannot be analyzed in isolation. A given feature, such as delayed development, can have multiple roles. Default responses can be either active (development continues unless signalled otherwise) or passive (development stops unless signalled otherwise), making necessary a broad approach to understanding the action of environmental cues. Even relatively minor effects that fine-tune dormancy responses enhance survival, but may be difficult to detect or measure. Trade-offs are not inevitable, not only when certain resources are surplus, but also because resources in very short supply (constraints) cannot be traded off. Life-cycle components are widely, but not universally, coordinated. These conclusions confirm that the range of dormancy responses is wider, more complex and more integrated than has often been recognized.
\end{abstract}

\section{INTRODUCTION}

Most insects change the rate of development, or even suppress development altogether (quiescence, diapause), to cope with environments that differ in quality from place to place or from time to time. Many reviews (e.g. Danks, 1987) have considered detailed developmental responses to environmental conditions, especially photoperiod. Even so, the breadth of the responses available to insects and the extent to which they are coordinated have not always been fully appreciated. This paper examines the range of such responses from a general perspective, rather than treating details such as the stage, seasonal placement or voltinism of particular species. Such an approach suggests how the responses integrate key environmental and developmental constraints, and generates conclusions that may be helpful for studying and understanding them. A broad approach seems useful too given recent emphasis on molecular, biochemical and genetic studies, most of which address operations of the detailed machinery that runs the life cycle, rather than its wider ecological context. Because most of the phenomena described are widespread, relatively few of the possible examples are cited here, and instances published more recently and not cited in earlier reviews are favoured.

The range of dormancy responses is very wide for four main reasons:

\section{Environmental differences}

Different environments have different temporal, especially seasonal, patterns, with different abiotic and biotic elements (e.g. climatic stresses, habitat stability, predation and competition). Depending on the environment, a focus on response to the seasons throughout the year (see Musolin \& Saulich, 1999 for an example of this approach), on seasonal stream discharge (Nolte et al., 1997) or on tidal patterns (Saigusa \& Akiyama, 1995) may be appropriate. Some habitats are non-seasonal, because conditions are similar throughout the year except for unpredictable changes (Towns, 1981; Yule \& Pearson, 1996). Of course, different species develop at different seasons in the same habitat. Some species are active in winter even in temperate environments (Aitchison, 1979). Maximum growth of some chironomid species occurs in winter (Berg \& Hellenthal, 1992). A springtail has a long egg diapause from spring to fall and grows and reproduces only in winter (Itoh, 1994). Moreover, because habitat as well as climate determines the conditions experienced, the effect on development of the different habitats occupied by different individuals may even be greater than the year-to-year effects of weather (e.g. Weiss et al., 1993, Weiss \& Weiss, 1998 for emergence times in a butterfly).

Theoretical analyses have emphasized the stability or permanence of habitats and their patchiness as the key 
templet for reproductive strategies (e.g. Greenslade, 1983; Southwood, 1988; Toda \& Kimura, 1997), although Statzner et al. (1997) pointed out that trade-offs and scale problems can obscure these relationships. Stress, with or without a temporal component, is another way to view the impact of environmental conditions on life histories; compare the discussions of Krebs \& Loeschcke (1999) and Parsons (1993).

Consideration of both specific factors and general theories thus shows environments to be so complex - in conditions, in time and in space — that almost any combination of life history features is possible (cf. Gaston \& Reavey, 1989 for Lepidoptera). Overgeneralizations are not wise (Hodek, 1999).

\section{Evolutionary differences}

Each species has a particular evolutionary history, which limits or favours aspects of its current adaptations. Therefore, the responses of related taxa tend to be broadly similar. For example, differences in the rates of development and of oviposition in phytoseiid mites vary significantly among subfamilies, genera and subgenera as well as among species (Zhang, 1995). Phylogenetic constraints therefore govern adaptive syndromes (Price, 1994), and some groups are limited to a particular range of conditions. The potential life-cycle traits of oribatid mites are constrained by slow development and other characteristic features (Norton, 1994). Broad phylogenetic constraints influence the overwintering stage, which is fixed in many species that enter diapause in that stage (e.g. Danks, 1987).

Evolutionary history is important at a more detailed level too, because life-history evolution of a given species has been to past rather than current habitat conditions (Pritchard et al., 1996) or to past rather than current competition (Ayal et al., 1999, p. 60). Related species with similar ecologies but different life histories may each have been trapped by historical accidents on different adaptive peaks (Schaffer, 1974). It is then difficult to interpret how particular adaptations developed if only their correlation with current environments is considered.

\section{Activity and resistance}

Insects need to grow and reproduce when conditions are favourable, a matter of timing of the feeding and reproductive stages. Synchrony of the population as well as its coincidence with the favourable season can be important too. Insects also need to survive conditions unsuitable for reproduction or development (typically in a season that is too cold or dry), a matter of both the timing of an inactive stage and its resistance to adversity. Therefore, adaptations assumed to respond to resistance may in fact respond instead to the timing of activity. For example, aestivation of a cholevid beetle serves to delay and so synchronize the life cycle, rather than to avoid deteriorating climatic conditions (Ehlert et al., 1997). Diapause in eggs of a grasshopper primarily prevents egg hatch at an inappropriate time of year, rather than conferring any additional resistance to desiccation over that of non-diapause eggs (Colvin, 1996).
Of course, such a balance is different in different species (Pener, 1997, p. 315, for Orthoptera). It is more likely to be weighted towards reproductive timing than towards resistance in subtropical compared to temperate strains (Tanaka, 1992 for a spider).

\section{Life-cycle coordination}

All responses of a species must be coordinated if the life cycle is to be completed successfully. Such a requirement forces the integration of many developmental and other traits (see Trade-offs and coordination).

\section{LIFE-CYCLE PROGRAMMES}

A series of steps is required to complete development. Therefore, different options can be included at various stages, and alternative dormancy responses are common in life-cycle pathways (Danks, 1987, 1991). Such alternatives include diapause or non-diapause, slow development or fast development, and diapause or quiescence. For example, in a cerambycid beetle, chilling averts diapause, and these quiescent larvae can catch up to larvae that have entered diapause (Shintani \& Ishikawa, 1997). Even diapause itself is a special form of development, not simply its prevention (Danks, 1987), with the expression of novel genes (Flannagan et al., 1998). The many options mean that, just as for "types" of diapause (cf. Danks, 1987 , pp. 12-16), it is difficult to develop any simple classification for the "types" of life cycle that occur in particular taxa (cf. Thiele, 1977; Nilsson, 1986).

Both genetic programmes and environmental responses contribute to the available options. The genotype heavily controls the diapause propensity of species such as the stored-product mite Lepidoglyphus destructor (Schrank) (Knülle, 1991). Some taxa have highly patterned sequences of morphs in successive generations, notably in aphids, which are pre-programmed for major adjustments in reproductive strategy through time, even though sex and morph determination are also under environmental control (e.g. Austin et al., 1996; Dixon \& Kundu, 1998; Helden \& Dixon, 1998; Erlykova, 1999). In at least a few species, an endogenous timer appears to set the response (e.g. Kipyatkov, 1994; Rasumova, 1995; Nishimura \& Numata, 1998). Environmental responses range from relatively simple ones, such as diapause development followed by a response to increasing temperatures in spring, providing seasonal synchrony, to complex responses to diverse environmental cues throughout the life cycle, ensuring appropriate seasonal coincidence of the stages (for examples see Topp, 1990, 1994; Danks, 1991, 1994a; Shindo \& Masaki, 1995; Tilley, 1996; Aoki, 1999).

The complexity of responses in typical individual species suggests that even modest fine-tuning of the response has selective advantages (Danks, 1994a, p. 17). For example, photoperiodic responses commonly are supplemented by small effects of food or moisture. The broad effects of a critical photoperiod are modified by the effects of change, or the critical daylength for later development changes according to earlier daylengths (Kimura \& Masaki, 1998). Very small percentages of individuals provide various kinds of survival insurance to the popula- 
tion (Danks, 1983). For example, a few females of some species overwinter more than once (such as $1.3 \%$ of individuals: Nelemans et al., 1989). Such effects are difficult to detect, and increase the complexity of necessary experiments.

\section{Degrees of developmental modification}

Developmental responses vary from a complete stoppage of development, through slow development, to the acceleration of development above normal. Responses can be all-or-nothing (such as the simple opposites of non-diapause and diapause) but also occur on a sliding scale, and both types of response can occur in a single species (e.g. Barker, 1992 for diapause, non-diapause and slowed development (under different conditions) in the larval stage of a moth; Tanaka et al., 1999 for the existence and the intensity of diapause in a cricket). Moreover, there is more than one way to effect a given pattern of development. Therefore, complete control over the seasonal coincidence of a given stage is potentially possible. The following examples illustrate part of the range of possibilities.

Many species respond to different conditions by changing the nature of the diapause or by growing at different rates during the same or subsequent instars (e.g. Danks, 1987, Table 33). In particular, complex life-cycle controls can be exercised if the direction of the responses, to photoperiod for example, changes as development proceeds (e.g. Kato, 1989; Danks, 1991; Tauber et al., 1998), or if changing photoperiods have different effects than stationary ones on the duration of diapause (Canard \& Grimal, 1993; Košt'ál \& Hodek, 1997) or on the rate of development (Kemp, 2000). Some species, but by no means all, respond to photoperiod in a quantitative or at least graded manner, with the rate of growth or the degree of developmental slowdown scaled to the photoperiod (Wassmer \& Page, 1993; Trimble, 1994; Suzuki \& Tanaka, 2000). Quantitative responses are seen in some species for the incidence of diapause, at least near the critical photoperiod (Kimura, 1990). In others, diapause intensity depends on the conditions during induction, of photoperiod (Nakamura \& Numata, 2000) or temperature (Glitho et al., 1991; Kalushkov et al., 2001), and in addition photoperiod can act directly during diapause development to change diapause intensity (Nakamura \& Numata, 2000). All of these quantitative effects allow the degree of response to be further refined.

A very common system for delaying development in larvae is the addition of extra moults, normally with an ongoing, although often relatively slow, increase in size. Many species have different numbers of instars under different conditions, especially of photoperiod and temperature, but also of directly limiting factors such as poor or reduced food or crowding. For information on a sample of species with a range of responses see $\mathrm{Li}$ et al. (1993) and Kamata \& Igarashi (1995) for Lepidoptera; Kawano \& Ando (1997) and Tanaka et al. (1999) for Orthoptera; and Shintani et al. (1996) for Coleoptera. Several species have stationary moults which do not result in an increase in size, and may even lead to size reduction: see Kfir
(1991) and Maruyama \& Shinkaji (1991) for Lepidoptera; Kotaki et al. (1993) and Gerard \& Ruf (1997) for Coleoptera.

The wide range of possible dormancy states and developmental rates partly reflects the fact that reductions in the rate of development have several different uses. For example, they can conserve energy, protect against adversity, synchronize the feeding stage with food resources, optimize the timing of reproduction, synchronize individuals, prevent a risky generation late in the year, or assist in further life-cycle programming by allowing environments to be monitored for a longer period. Changes in developmental rate (including additional larval moults) in effect make "extra" time available during development, time that is put to a variety of uses. For example, extra developmental time can be used to store reserves for a subsequent dormancy (Novakova \& Nedvěd, 1999 for Pyrrhocoris). However, some species appear simply to "waste" the time without feeding. Longer developmental times that take a given stage later into the year, and hence into longer or shorter daylengths, increase or reduce diapause incidence and so influence the number of annual generations (e.g. Ishihara, 2000).

These examples confirm that the structure of life cycles varies from unimodal responses, such as one obligate diapause seasonally and direct development at the normal rate at other times, to polyvalent systems using a wide range of simultaneous and successive developmental options. Many complete stoppages of development coincide with adverse seasons, whereas most growth-rate adjustments fine-tune the response to optimize the seasonal coincidence of appropriate stages (Danks, 2001).

\section{Number of components}

Developmental options are especially diverse because both life cycles and their individual dormancy responses consist of a number of successive components. Although many species have a single main dormant period annually, many others structure the life cycle by means of multiple diapauses in the same or different stages, which enforce seasonal coincidence and also commonly synchronize reproduction. For example, diapauses in successive larval instars can generate life cycles lasting up to several years (e.g. Wipking and Mengelkoch, 1994 for Zygaena; Nishizuka et al., 1998 for Lepisma). More typically, such forced pauses in development adjust the life cycle so that it lasts for exactly one year (e.g. Goddeeris, 1990 for Tanytarsus).

Successive potential diapauses are also known within a single stage, as in eggs of several species of Orthoptera (e.g. Ingrisch, 1986; Niva \& Becker, 1998). Similarly, in several species of adults, contrary to earlier opinion, diapause can be reinduced, normally by photoperiod, so that reproductive patterns in the adult stage are programmed into two or more subsets (see e.g. Hodek, 1971, 1979; Van Houten et al., 1991; Hodek \& Hodková, 1992; Nakai \& Takeda, 1995; Nakamura et al., 1996; Nakamura \& Numata, 1998; Inoue et al., 2000).

There are multiple substages even during a single diapause. Diapause development usually consists of two or 
more distinct developmental phases (e.g. Lavenseau \& Hilal, 1990), so that its end is not always governed simply (see Life-cycle control). For recent examples and discussion see Wipking (1995), Johnsen et al. (1997), Nomura \& Ishikawa (2000) and Gray et al. (2001). Similarly, ovarian diapause comprises several seasonally coordinated steps rather than a simple arrest in reproduction (Košt'ál \& Šimek, 2000). Of course, even normal development consists of a series of substages such as growth periods and moulting periods, the latter comprising as much as half of the total time in some insect species (Ayres \& MacLean, 1987; Ayres \& Scriber, 1994).

Finally, successive responses commonly are linked. For example, diapause affects subsequent fecundity or other life-cycle traits in some species (e.g. Ishihara \& Shimada, 1994; Ishihara, 1999). Many species that enter diapause grow more slowly in the preceding stage(s) (Johnsen \& Gutierrez, 1997; McGregor, 1997), even in parasitoids (e.g. Nealis et al., 1996). Among other possible benefits, longer feeding may permit a greater size, a potential prerequisite for survival during diapause. Conversely, slower growth in one stage may be compensated for by faster growth in a later stage (e.g. Volney \& Liebhold, 1985) or females maturing later may lay eggs earlier in their life span and over a shorter period than those maturing early, ensuring offspring survival albeit at the expense of fecundity (e.g. Landa, 1992). Nymphs of a bug develop faster in short days, which induce reproductive diapause in subsequent adults (Ruberson et al., 1991).

The fact that many successive components make up a given life cycle or a given dormancy permits the precise control and execution of appropriate developmental pathways.

\section{Life-cycle duration}

The duration of the life cycle depends on how developmental responses are coordinated. Typical multivoltine species have a single dominant life-cycle control such as diapause to constrain development for the adverse season, but many generations with rapid development succeed one another during the active season.

In other species, each generation follows the same annual pattern and the life cycle is strictly univoltine. Some of these species have a single extended diapause, for example more than 9 months for the bamboo borer Omphisa fuscidentalis Hampson (Singtripop et al., 1999). Other univoltine life cycles are controlled by repeated diapauses and growth-rate responses.

Life cycles of a few species always take more than one year (Brandmayr \& Brandmayr, 1986; Danks, 1992; Kaplin, 1995; Barton et al., 1996; Townsend \& Pritchard, 1998), even in the tropics (Sweeney et al., 1995 for a mayfly). Like the univoltine species, such species may have one or a combination of slow development (Aoki, 1999), slow dispersed growth and reproductive effort (Chaabane et al., 1977), extended diapause (DeWalt \& Stewart, 1995 for some semivoltine stonefly species; Köhler et al., 1999) and repeated diapause (Higaki \& Ando, 1999).
An interesting set of species has complex life cycles of variable duration, often resulting from cohort splitting. Typically, one part of the cohort emerges the year before the other. Such patterns are best characterized in aquatic species (e.g. Aoki, 1999) but are known also in terrestrial environments (e.g. David et al., 1999).

Alternatively, or in addition, larval numbers and sizes are spread out over time, not just separated into two temporal groups. For example, the stonefly Agnetina capitata (Pictet) maximizes such a spread by means of variable and delayed egg hatch, extended adult emergence, and a long oviposition period (Moreira \& Peckarsky, 1994). Some caddisfly species have wide variation in developmental rates, overwintering in different larval stages, and asynchronous extended flight periods (Sangpradub et al., 1999). Separate cohorts may coexist in the same year (Lindegaard \& Mæhl, 1993 for two Heterotrissocladius species), although apparently they are not reproductively isolated. The life cycles of several Hexagenia mayflies are characterized by marked variability in development and overlapping cohorts (Giberson \& Rosenberg, 1992b, 1994). Some Australian mayflies have asynchronous life cycles of variable duration, e.g. 0.5 to 3 years (Campbell, 1986). More complex life cycles, especially the longer variants, lead to overwintering in a variety of instars or different stages (e.g. Tanaka \& Uemura, 1996; polyvariant life cycles of Sharova \& Denisova, 1997).

These differences in life-cycle duration and variability among and within species appear to be correlated chiefly with two environmental features, the level of resources and the degree of habitat stability. Very long life cycles are most prevalent in habitats and regions that are cold, such as the arctic, and that supply poor quality food, such as wood (Danks, 1992).

Slow conservative life cycles tend to accord with stable, though not always cool, habitats ("K-strategy"), and also may serve to avoid intraspecific competition (Tasch \& Topp, 1991 for the mole-nest staphylinid beetle Quedius ochripennis Ménétries). Univoltine species are more susceptible to habitat disturbance than multivoltine ones, because they cannot recolonize as readily (Tiemann \& Arsuffi, 1991). Such a conclusion is confirmed by the fact that spiders from older habitats tend to be univoltine, and those from disturbed ones multivoltine (Draney \& Crossley, 1999). Cohort splitting and wide temporal spread of the members of a cohort, as well as high adult mobility and generalist habitats (Townsend et al., 1997), likewise can compensate for habitats or seasons that are disturbed or unpredictable (habitat stability and unpredictability are considered further under Variation). Overwintering in multiple stages may extend the reproductive season and buffer the population against adverse fall or spring weather (Murray \& Giller, 1991).

\section{LIFE CYCLE CONTROL: ACTIVE OR PASSIVE DEFAULTS}

Control of seasonality ranges from simple direct temperature control (Logan \& Bentz, 1999 and Powell \& Jenkins, 2000 for Dendroctonus) to extremely complex 
responses to a range of cues (e.g. Ikeda-Kikue \& Numata, 1992, 1994; Danks, 1994a). Cues include those like plant quality drawn from the current insect habitat, those like photoperiod not specific to the habitat, and maternal influences (Stadler, 1992). Here, I focus not on details of control by particular cues, but rather on the more general concept of active default versus passive default responses, because I believe that many problems in understanding dormancy stem from a failure to appreciate that patterns of development have different default settings in different species, a concept briefly introduced by Danks (1987, p. 279; 2001).

When the default is active, normal development goes on unless some alternative is specifically signalled or induced. For example, the normal developmental rate depends only on temperature (governing metabolic rate). Specific environmental cues are then required to alter developmental rate or induce diapause. Diapause elapses spontaneously and does not need specific cues or a sequence of cues to end.

When the default is passive, development stops even if conditions do not change. For example, diapause takes place whatever the environment and ends only when signalled to do so by certain changes in conditions.

Such a concept can be applied not only to developmental rate and diapause, but also to instar number, wing development, and seasonal morph. The active-passive distinction was implied in Müller's (1970) term "parapause" for obligate diapause requiring environmental change for development to resume. Hodek $(1981,1983)$ coined the terms horotelic, for processes of diapause development that take place at a standard rate as intrinsic inhibition diminishes, and tachytelic, for processes that occur at a faster rate stimulated by outside influences. For a recent example see Košt'ál et al. (2000).

Actual life cycles reflect one or a combination of active and passive alternatives. Most species develop most of the time automatically (active), but include in their life cycles one or a few key control points, such as winter diapause induced by short days.

Species in which the default is passive (development stops unless signalled otherwise) have created particular confusion. So-called "obligate" diapause under constant conditions might be simply an automatic or endogenous suppression of development for a period independent of conditions. But such a diapause might instead end as soon as there is a specific required change in cues. Furthermore, because diapause development in many species can go on either spontaneously or in response to external cues, the environmental programme required to end a given diapause changes through time.

In many species, the change of conditions required to end "obligate" diapause consists of only two steps (Danks, 1987, Table 23). Commonly only simple photoperiodic changes are required, e.g. long days then short days, albeit sometimes across several developmental stages (Haderspeck \& Hoffmann, 1990). Two-step responses to temperature for diapause development are common too (e.g. Worland et al., 2000), though often not clear cut (Kim et al., 1990; Tzanakakis \& Veerman, 1994). Other species use a change in foodplant cues (Glitho et al., 1996). However, in several species requirements to end diapause are complex and multiple, allowing many different life-cycle durations including very long dormancies.

Nevertheless, some commitments to development can be reversed. For example, diapause intensity in Locusta eggs is reduced or restored by temperature (Ando, 1993); male reproductive diapause is reversible in many orthopterans (Orshan \& Pener, 1979); examples of the reinduction of adult diapause were cited under Number of components. "Induction" and "deinduction" take place at the higher control level according to Zaslavski (1995). Such reversibility is not unlimited. After a given stage has been reached, development cannot be reversed. For example, in some species once fat has been allocated to eggs it cannot be resorbed and used for survival (Ellers \& van Alphen, 1997). Even in aphids, only younger embryos can be resorbed (Stadler, 1995). Once cells have differentiated beyond a certain stage alternative developmental outcomes are no longer possible.

The passive-active concept also forces consideration of which alternative - a commitment to development or to non-development - is "normal". Although many authors have assumed that development rather than dormancy, winged rather than wingless morphs, the absence rather than the presence of hormones to control diapause, and so on, are "normal", basic developmental patterns of this sort in fact depend on the species and its past and current habitats, because the adaptive value of the different responses is linked to the pattern of habitat suitability for a particular species.

In general, passive, conservative or fail-safe responses are prevalent in species from more severe or unpredictable habitats. There, conditions are often unsuitable and moreover current environmental signals might not give useful information about habitat suitability in the near future. For example, "obligate" diapause, long diapauses relatively insensitive to external cues, two-stage or multiple-stage responses, and other very narrow requirements for diapause-free development are most common in habitats such as the arctic (cf. Danks, 1981) and places with intermittent drought (cf. Wardaugh, 1986). In less severe habitats, on the other hand, conditions are generally suitable for activity, and moreover reliable environmental cues provide information that allows dangerous conditions to be avoided by adjusting the rate of development, the onset of diapause, or the end of diapause development. Monitoring environmental signals as late as possible in development normally gives the most useful information (Danks, 1987, p. 80, for diapause induction; Kooi \& Brakefield, 1999 for wing-pattern induction)

In summary, passive defaults are especially valuable where environments are severe or where short-term environmental signals might be misleading; active responses would be likely to expose vulnerable individuals to danger. Active modes take advantage of conditions that are 
generally suitable; under the same circumstances opportunities would be missed if the default were passive.

\section{VARIATION}

Organisms differ in the degree of variation, its genetic or environmental basis and its responsiveness to current environments. These patterns reflect natural environmental patterns. Geographic variation among populations has been treated in detail in many past reviews (Danks, 1987, pp. 160-173; Masaki, 1996, 1999; and references cited there) and is not considered further here.

Part of the variation among individuals stems from genetic differences. Continuous variation, typically normally distributed, occurs in all traits of course, but in some species the range of continuous variation is very wide and not necessarily normally distributed (some examples were cited under Life-cycle duration). Commonly the variants are divided into two or more subsets (polymorphism) (cf. Danks, 1994b), as discussed later in this section. Genetic variation is maintained at a relatively high level in natural populations. The heterogeneity of environments means that no one genotype is suitable for them all: genotype-environment interactions are pervasive (e.g. Brakefield \& Kesbeke, 1997) and help to maintain variation in developmental and other characters (for sample information see Gebhardt \& Stearns, 1992; Rochat et al., 1999; Jia et al., 2000; Iriarte \& Hasson, 2000 ). Depending on the way of life of the species, such differences can be maintained on a very small scale, even between individual trees in the aphid Kaltenbachiella japonica (Matsumura) (Komatsu \& Akimoto, 1995). Not all genotypes are exposed to selection in any given generation. A pool of dormant individuals helps to slow evolution (Hairston \& Stasio, 1988). Moreover, diapause genetics is relatively complex and organisms have specific genetic mechanisms to retain variation. Therefore it is very difficult to eliminate diapause completely in most species even by strict laboratory selection (cf. Danks, 1987, Table 30).

At one extreme, development is canalized. The response is highly conserved to reduce phenotypic variation, and thereby protected against environmental perturbation by temperature or other factors, and against genetic change by mutation and recombination. Such canalization is usually most visible for traits that have the greatest impact on fitness (Stearns \& Kawecki, 1994). However, canalization is less effective in unusual or difficult environments (cf. Kawecki, 1995).

Variation among individuals can stem too from plasticity, different responses to different environments by the same genotype (Sakwinska, 1997; Nylin \& Gotthard, 1998). Many developmental features can be adjusted and many cues can be used for the adjustment (see Danks, 1987, 1994a). For example, larval development of many Lepidoptera is continuously modified by interpreting cues such as photoperiod that indicate season and hence the remaining duration of suitable conditions, including the likelihood of "time stress" if the interval remaining for development is too short before winter (Nylin, 1994; Got- thard et al., 2000). Features including especially size, time and growth rate, but also sex (e.g. protandry), reproductive effort, morph, and dormancy can be adjusted in a cooordinated manner (Banno, 1990; Nylin, 1994; Gotthard et al., 1994, 1999; Brakefield, 1996; Fisher \& Fiedler, 2000, 2001; Stockley \& Seal, 2001). In locusts, morph, activity, food consumption, developmental rate and other more subtle changes give extraordinary phenotypic plasticity (Pener \& Yerushalmi, 1998).

Both genetic and plastic elements are integrated in a given species. There are genetic differences in plasticity, of course. Normally both genetic and plastic responses are combined in the same stage (Bradford \& Roff, 1995) and in the same life cycle (Fangsen \& Kallenborn, 1998).

Whether fixed genetic or labile plastic responses predominate depends on habitat characteristics. A stable habitat can best be exploited by a fixed genotype and different stable regional habitats by local genetic adaptation. However, when habitats are variable or heterogenous on a small scale, plasticity allows adjustment to the particular subhabitat encountered by a given individual, and general genetic patterns that can be modified by local responses predominate. By the same token, panmictic populations that cannot adapt to regional environments because gene flow is too great can make local plastic adjustments instead: flexible multi-purpose genotypes are then favoured (Blanckenhorn, 1997).

When environments are variable and they provide clues that both indicate future change and can be monitored effectively, plasticity is favoured because it allows effective adjustment to the changes. However, in some variable habitats environmental signals do not predict future conditions. For example, a statistically "mean" rainfall year occurs only every 50 years in the west African Sahel (Launois et al., 1996). In such environments, which prevent adequate plastic adjustments, several fixed genetic morphs or a very wide range of variation that spread developmental types through time are favoured instead. Such multiple groups or widely spread individuals provide insurance against risks that occur in no predictable pattern, and so are a form of "bet hedging" (see Frank \& Slatkin, 1990 for sample theory). Bimodal emergence achieves this spread (see Danks, 1987, Table 27; Goulson, 1993; Biron et al., 1999). So does asynchrony (e.g. Courtney, 1991 for deuterophlebiid life histories in streams with unpredictable spates; Neal et al., 1997 for egg hatch of Malacosoma where there may be late winter storms; Zwick, 1996, and noted above, for staggered egg hatch in aquatic species such as many stoneflies).

Instances of prolonged diapause (diapause for more than one adverse season) are especially interesting in this context because they are relatively common (Danks, 1987, pp. 190-192; Hanski, 1988; Hanski \& Ståhls, 1990; Neff \& Simpson, 1992; Sharov, 1993; Markov, 1997; Menu et al., 2000). Prolonged diapause even appears in low proportions in species that do not live in especially unpredictable environments (e.g. Gerson et al., 1999). Menu (1993) and Menu \& Debouzie (1993) characterize these responses as "coin-flipping plasticity", or stochas- 
tic polyphenism (Walker, 1986), but the results observed for prolonged diapause in several species would be consistent with polymorphism for induction (leading to a risk-spreading resource of morphs with prolonged diapause potential), coupled with some environmental control especially for the end of diapause (compare Danks, 1987, p. 185; Hanski \& Ståhls, 1990; Sweeney \& Gesner, 1997). Such a feature would parallel on a longer time scale the discretionary end of post-diapause quiescence in many species. In addition to accumulated temperature, some species require further stimuli before development will resume. For example, hatching of some mosquito eggs requires stimuli from oxygen tension, microorganism growth or conspecific larval density (Wood et al., 1979; Edgerly \& Marvier, 1992).

The wide occurrence of bet-hedging strategies suggests that when interpreting life histories it is valuable to give explicit consideration to asynchrony, bimodal emergence and prolonged diapause, even when they are rare.

\section{TRADE-OFFS AND COORDINATION}

Successful development and reproduction require that all environmental challenges are met. Therefore, other life-cycle elements must be coordinated with dormancy responses.

The role of trade-offs in such cordination has attracted considerable general and theoretical discussion, with a focus on the effect of trade-offs on demographic parameters such as $r_{m}$ and $R_{0}$. In $r$-selected species such as aphids, for example, resource/size trade-offs maximize $r_{m}$, (Kindlmann \& Dixon, 1992). In the present context, especially life-cycle timing and the use of resources might be traded off (for examples and further references see Roff, 1992; Stearns, 1992; Danks, 1994a; Abrams at al., 1996; Nylin \& Gotthard, 1998). Trade-offs reflect the differential protection of resources, whereby one factor is conserved or enhanced at the expense of another. Factors that can be traded off include all of the features adjusted by the characteristic dormancy responses already noted, such as size, developmental time, growth rate, various components of diapauses and their incidence and duration, morph, instar number, fecundity, patterns of oviposition, life span, resistance to adversity, parental care, maternal influences, stored reserves and activity. But there are few constant relationships: even the well-known correlation between larval size and adult fecundity depends on whether adults feed or not (McPeek \& Peckarsky, 1998). Nylin \& Gotthard (1998, and other papers) have emphasized the fact that growth rate itself can be modified, so that size and time do not necessarily have to be traded off.

Trade-offs can be simple, or complex and difficult to measure (e.g. Tschinkel, 1993; Schwartzkopf et al., 1999), and can span stages (Bradshaw \& Holtzapfel, 1992 for the effect of larval food on adult fecundity in Wyeomia).

Most existing studies emphasize relatively simple sizetime relationships, but trade-offs are diverse. For example, grasshopper eggs deposited deeper are better protected, but hatchling emergence is more difficult (Car- riere et al., 1997). Grasshoppers in vegetation obtain more food and experience warmer conditions higher up, but there they suffer more predation from vertebrate predators such as birds. The grasshoppers predominate at intermediate height even though it does not provide the optimal temperature for development (Pitt, 1999).

Of course, trade-offs differ among species, because whether time, size (or its correlates - see Klingenberg \& Spence, 1997), or other factors are most important depends on the species. Some species maintain size at the expense of slower development; others maintain developmental rate (Danks 1994a, p. 10). Moreover, trade-offs in the same factors can differ between generations. For example, larger eggs may be advantageous later in the year for growing larger individuals when there is less time before winter (cf. Fitzpatrick \& Troubridge, 1993; Mappes et al., 1996). Trade-offs also differ between the sexes of one species. Males tend to minimize development and pre-mating time, often at the expense of size (e.g. Baker et al., 1992; Zonneveld, 1996), whereas females tend to maximize mass, typically for fecundity (e.g. Kleckner et al., 1995; Fischer \& Fiedler, 2001), but also for flight range for example (McLachlan, 1986). Nutrient transfers from male to female during mating can further modify these relationships (e.g. Karlsson, 1995).

Unfortunately, such a range of possibilities makes the prediction of resource trade-offs for a given species, to help in planning research, no more reliable than predicting its dormancy responses in advance. Another problem is that the response of a given strain depends on the assay environment (Ackermann et al., 2001), so that dissimilar results, especially for fecundity, can come from different tests.

Although useful generalizations have been derived from "trade-off" theory, viewing every feature as subject to trade-offs is not helpful. Priority items, notably survival, will be protected first (Stearns, 1992, p. 109). Complex life histories may generate misleading conclusions. For example, egg hatch in the tree-hole mosquito Aedes triseriatus Say generates asynchronous larvae, reducing competition (Edgerly \& Livdahl, 1992), so that experimental assessments of the trade-offs made with crowded individuals may not be relevant to the life cycle in nature.

Most importantly, conditions often act simply as direct constraints that prevent or limit potential trade-offs within a particular species. If resources are severely limited growth will be at the maximum allowed by the resources, and there can be no trade-off involving time or size. For example, limited food resources usually determine final size directly (Giberson \& Rosenberg, 1992a; Tammaru, 1998); adopting a longer season in order to grow bigger instead is not necessarily an option. Undersized blowfly larvae develop directly; resource-dependent diapause is not an option (Saunders, 1997). Trade-offs are constrained by nitrogen limitation in the food, which lowers fecundity, egg development, larval growth rate and survival in a moth (Taylor, 1988). Although predation can dictate growth rate or voltinism and so may be traded off, in most cases pressure from predators decreases perform- 
ance directly through disturbance or mortality, with no option to trade off time adaptively - as has often been theorized - by speeding up development to reduce the risk of predation (Martin et al., 1991; Peckarsky et al., 1993; Ball \& Baker, 1995); but see Peckarsky et al. (2001).

The relevance of examining constraints and not just emphasizing trade-offs is confirmed by the fact that natural populations of some species are nutritionally stressed year round. Wild individuals of Drosophila buzzatti Patterson \& Wheeler are $25 \%$ smaller at a given temperature than they would be in the laboratory (Thomas, 1993). Such findings suggest that many species may have relatively little life-cycle trade-off room. In contrast, attention has been captured mainly by conspicuous examples where, at least at some times of year, resources or time are potentially surplus (Nylin et al., 1989), enabling clear trade-offs to be made according to other factors.

Life cycles are governed centrally through linkage among serial or simultaneous components, whether or not there is explicit linkage through resource trade-offs. Again, however, specific coordination depends on the species, and many "expected" linkages in fact are not present. Different traits can be more or less closely connected: for example, cold hardiness is linked to diapause or its intensity in various species (Pullin, 1990; Langer \& Hance, 2000; Watanabe \& Tanaka, 2000). But the same traits may instead be independent or not correlated: cold hardiness and diapause are independent or partly independent in other species (Tanaka, 1994; Saunders \& Hayward, 1998; Goto et al., 2001; Kalushkov et al., 2001). Kalushkov \& Nedvěd (2000) showed for a bug that diapause is a prerequisite for acclimation to cold, but coldhardiness changes in winter independent of diapause. Colour maturation of a dragonfly is independent of sexual maturation (Euda, 1989). Observed correlations may stem from unexpectedly complex connections among traits (e.g. Danks, 2000 for cold hardiness and dehydration).

Some correlations reflect the fact that even traits that are independently controlled may use the same inductive cue such as photoperiod, which indicates the time of year with great reliability. Morph and sex are controlled independently by photoperiod in an aphid (Lees, 1990). Wing and oocyte development are induced by photoperiod at different instars in a gerrid (Inoue \& Harada, 1997). Development of reproductive structures stops in one day but growth takes three days to slow down to the short-day rate when larvae of a drosophilid fly are moved from long days to short days (Košt'ál et al., 2000). Diapause of a bug is governed by a critical photoperiod, but body colour responds through a gradual (quantitative) photoperiodic response (Numata \& Kobayashi, 1994).

Such findings force us once again to consider the life cycle as a whole, and to maintain a broad view in order to understand how its elements are coordinated. For example, responses to habitat conditions are integrated through wing length, dispersal capacity and reproductive pattern, as well as through a rich array of developmental responses, producing diverse syndromes of migration, diapause and life history on various scales (for recent discussion see Den Boer \& Van Dijk, 1996; Zera \& Denno, 1997; Svensson, 1999). However, it is especially important to remember that elements such as flight and developmental rate have multiple roles. Thus flight in gerrids serves in foraging and escape from enemies as well as in its generally assumed bet-hedging role through dispersed reproductive output (Spence, 2000). Developmental timing can have many simultaneous functions.

\section{CONCLUSIONS}

In this paper I have tried to illustrate the great range of dormancy responses, as well as to highlight a few conclusions that may be helpful in understanding them.

Many options are available. The number of subcomponents and their ranges of expression are so wide (Table 1) that it is easy to underestimate the potential complexity of dormancy responses and the possible differences among species and populations. These complexities reflect the enormous range of environments potentially inhabited by insects.

Any particular set of responses reflects evolutionary history. Adaptations respond to past environments as well as to current ones, hindering the interpretation of observed correlations.

It is not necessarily obvious what kind of selection explains a particular life cycle. Adaptations that govern development can reflect mainly the need to time reproduction during a favourable season, mainly the need for a resistant stage during the adverse season, or both.

Developmental pathways have multiple components. Dormancy responses contribute to life-cycle pathways (Danks, 1991) that integrate the whole of development and its environmental setting. Therefore, analyzing components in isolation is of limited value (Danks, 2001).

A given feature can have multiple roles. Developmental rate can pertain to reproductive timing, competition, sexual selection, food quality, resistance to starvation, and other requirements.

Default responses can be active or passive. The fact that either development or dormancy might occur unless conditions change makes necessary a broad approach to understanding the action of environmental cues, again from the viewpoint of pathways of development.

Even relatively minor effects are important because they have significant selective advantages. Such fine-tuning (for example, food quality modifying the dominant photoperiodic response, rare extreme variants) may nevertheless be difficult to detect or measure.

Constraints may trump potential trade-offs. Trade-offs are not inevitable, not only because trade-offs are unnecessary if key resources are surplus, but also because resources in very short supply (constraints) cannot be traded off. 
TABLE 1 . Summary of the range of elements contributing to insect dormancy responses (partly after Danks 2001)

\begin{tabular}{|c|c|c|}
\hline Element & One extreme of the response & The other extreme of the response \\
\hline Default developmental response & Active development & Passive delay \\
\hline Type of response & Single, fixed & Continuous, plastic \\
\hline Type of delay & Minor slowdown & Complete arrest \\
\hline Type of life-cycle control & Direct, single factor ("quiescence") & $\begin{array}{l}\text { Indirect, multiple factors (diapause and related } \\
\text { responses) }\end{array}$ \\
\hline Sensitivity to environmental cues & $\begin{array}{l}\text { None ("obligate"; or direct regula- } \\
\text { tion only) }\end{array}$ & Continuously responsive \\
\hline Effective current cues & None & $\begin{array}{l}\text { Some or all of photoperiod, temperature, thermope- } \\
\text { riod, moisture, food, and others }\end{array}$ \\
\hline Type of sensitivity & Qualitative, fixed & Quantitative, and may change through stage \\
\hline Sensitive stage & One & Many \\
\hline Responsive stage & One, same as sensitive stage & $\begin{array}{l}\text { Many, same as or different from sensitive stage, } \\
\text { linked }\end{array}$ \\
\hline Number of dormancies in the life cycle & One & Multiple or successive ("programme") \\
\hline $\begin{array}{l}\text { Number of successive diapause induc- } \\
\text { tions possible }\end{array}$ & One & Several ("reinduction", "re-entry") \\
\hline $\begin{array}{l}\text { Number of components in a single dor- } \\
\text { mancy }\end{array}$ & One or few & Many \\
\hline Duration of life cycle & Days & Years \\
\hline Duration of dormancy & Short, fixed & Long or very long, variable \\
\hline Default diapause-ending response & Standard rate ("horotelic") & Accelerated rate ("tachytelic") \\
\hline Number of alternative life-cycle routes & None (fixed or simple life cycle) & Many (multiple pathways, complex life cycles) \\
\hline Variability & Little variation, normally distributed & Wide or discontinuous variation, programmed \\
\hline
\end{tabular}

Life-cycle components are widely, but not universally, coordinated. There are many potential linkages, but any given element is not necessarily linked with any other element. Their relationships depend upon the particular life cycle and how its various facets are integrated.

These concepts confirm the enormous range of possible dormancy responses in insects, and reinforce the need to analyze them with an appreciation of their extraordinary range and complexity. The context derived from the full range of possibilities helps to inform the design and conclusions of work focussed on specific details.

\section{REFERENCES}

Abrams P.A., Leimar O., Nyuin S. \& Wiklund E. 1996: The effect of flexible growth rates on optimal sizes and development times in a seasonal environment. Am. Nat. 147: 381-395.

Ackermann M., Butlsma A., James A.C., Partridge L., Zwaan B.J. \& Stearns S. 2001: Effects of assay conditions in life history experiments with Drosophila melanogaster. J. Evol. Biol. 14: 199-209.

Artchison C.W. 1979: Winter-active subnivean invertebrates in southern Canada. I. Collembola, II. Coleoptera, III. Acari, IV. Diptera and Hymenoptera. Pedobiologia 19: 113-120, 121-128, 153-160, 176-182.

ANDO Y. 1993: Thermal response and reversibility of diapause in the eggs of Locusta migratoria. Physiol. Entomol. 18: 1-6.

AoKI T. 1999: Larval development, emergence and seasonal regulation in Asiagomphus pryeri (Selys) (Odonata: Gomphidae). Hydrobiologia 394: 179-192.

Austin A.B.M., Tatchell G.M., Harrington R. \& Bale J.S 1996: Adaptive significance of changes in morph production during the transition from parthenogenetic to sexual reproduction in the aphid Rhopalosiphum padi (Homoptera: Aphididae). Bull. Entomol. Res. 86 : 93-99.

Ayal Y., Broza M. \& Pener M.P. 1999: Geographical distribution and habitat segregation of bushcrickets (Orthoptera: Tettigoniidae) in Israel. Isr. J. Zool. 45: 49-64.

AYres M.P. \& MacLean S.F.Jr. 1987: Molt as a component of insect development: Galerucella sagittariae (Chrysomelidae) and Epirrita autumnata (Geometridae). Oikos 48: 273-279.

AYres M.P. \& SCRIBER J.M. 1994: Local adaptation to regional climates in Papilio canadensis (Lepidoptera: Papilionidae). Ecol. Monogr. 64: 465-482.

Baker R.L., Forbes M.R.L. \& Proctor H.C. 1992: Sexual differences in development and behaviour of larval Ischnura verticalis (Odonata: Coenagrionidae). Can. J. Zool. 70: 1161-1165.

BALL S.L. \& BAKER R.L. 1995: The non-lethal effects of predators and the influence of food availability on life history of adult Chironomus tentans (Diptera: Chironomidae). Freshwat. Biol. 34: 1-12.

BANNo H. 1990: Plasticity of size and relative fecundity in the aphidophagous lycaenid butterfly. Ecol. Entomol. 15: 111-113.

BARKER J.F. 1992: Diapause in laboratory reared banded sunflower moths, Cochylis hospes Walsingham (Lepidoptera: Cochylidae), in relation to temperature and photoperiod. $J$. Kans. Entomol. Soc. 65: 431-434.

Barton T.R., Harris M.P., Wanless S. \& Elston D.A. 1996: The activity periods and life-cycle of the tick Ixodes uriae (Acari: Ixodidae) in relation to host breeding strategies. Parasitology 112: 571-580.

Berg M.B. \& Hellenthal R.A. 1992: Life histories and growth of lotic chironomids (Diptera: Chironomidae). Ann. Entomol. Soc. Am. 85: 578-589. 
Biron D.-G., Brunel E., Nenon J.-P., Coderre D. \& Boivin G 1999: Etude preliminaire du determinisme génétique contrôlant l'expression de l'emergence bimodale de Delia radicum (Diptera: Anthomyiidae). Annls Soc. Entomol. Fr. 35 (Suppl.): 104-108.

BlanCKenHorn W.U. 1997: Altitudinal life history variation in the dung flies Scathophaga stercoraria and Sepsis cynipsea. Oecologia 109: 342-352.

BradFord M.J. \& Rofr D.A. 1995: Genetic and phenotypic sources of life history variation along a cline in voltinism in the cricket Allonemobius socius. Oecologia 103: 319-326.

Bradshaw W.E. \& Holzapfel C.M. 1992: Reproductive consequences of density-dependent size variation in the pitcherplant mosquito, Wyeomyia smithii (Diptera: Culicidae). Ann. Entomol. Soc. Am. 85: 274-281.

BraKefield P.M. 1996: Seasonal polyphenism in butterflies and natural selection. Trends Ecol. Evol. 11: 275-277.

Brakefield P.M. \& Kesbeke F. 1997: Genotype-environment interactions for insect growth in constant and fluctuating temperature regimes. Proc. R. Soc. Lond., Ser. B: Biol. Sci. 264: $717-723$

Brandmayr P. \& Zetto Brandmayr T. 1986: Phenology of ground beetles and its ecological significance in some of the main habitat types of southern Europe. In: den Boer P.J., Luff M.L., Mossakowski D. \& Weber F. (eds): Carabid Beetles. Their Adaptations and Dynamics. Gustav Fisher, Stuttgart, New York, pp. 195-220.

CAMPBell I.C. 1986: Life histories of some Australian siphlonurid and oligoneurid mayflies (Insecta: Ephemeroptera). Aust. J. Mar. Freshwat. Res. 37: 261-288.

CANARD M. \& GRImal A. 1993: Multiple action of photoperiod on diapause in the green lacewing Mallada picteti (McLachlan) (Neuroptera Chrysopidae). Boll. Ist. Entomol. "Guido Grandi", Univ. Stud. Bologna 47: 233-245.

CARrIERE Y., MasaKI S. \& RoFF D.A. 1997: The coadaptation of female morphology and offspring size: A comparative analysis in crickets. Oecologia 110: 197-204.

Chaabane K., Loreau M. \& Josens G. 1997: Growth and egg production in Abax ater (Coleoptera, Carabidae). Pedobiologia 41: 385-396.

CoLvin J. 1996: Diapause duration, survival in relation to desiccation and egg-pod morphology of the Senegalese grasshopper, Oedaleus senegalensis. Physiol. Entomol. 21: 173-178.

Courtney G.W. 1991: Life history patterns of Nearctic mountain midges (Diptera: Deuterophlebiidae). J. N. Am. Benthol. Soc. 10: 177-197.

Danks H.V. 1981: Arctic Arthropods. A Review of Systematics and Ecology with Particular Reference to the North American Fauna. Entomological Society of Canada, Ottawa, 608 pp.

DANKS H.V. 1983: Extreme individuals in natural populations. Bull. Entomol. Soc. Am. 29: 41-46.

Danks H.V. 1987: Insect Dormancy: An Ecological Perspective. Biological Survey of Canada (Terrestrial Arthropods), Ottawa, $439 \mathrm{pp}$.

DANKs H.V. 1991: Life-cycle pathways and the analysis of complex life cycles in insects. Can. Entomol. 123: 23-40.

DanKs H.V. 1992: Long life cycles in insects. Can. Entomol. 124: $167-187$

DANKs H.V. 1994a: Diversity and integration of life-cycle controls in insects. In: Danks H.V. (ed.): Insect Life-Cycle Polymorphism: Theory, Evolution and Ecological Consequences for Seasonality and Diapause Control. Kluwer Academic Publishers, Dordrecht. Series Entomologica 52, pp. 5-40.

Danks H.V. (ed.). 1994b: Insect Life-Cycle Polymorphism: Theory, Evolution and Ecological Consequences for Seasonality and Diapause Control. Series Entomologica 52. Kluwer Academic Publishers, Dordrecht, Netherlands, $376 \mathrm{pp}$.

Danks H.V. 2000: Dehydration in dormant insects. J. Insect Physiol. 46: 837-852.

DANKS H.V. 2001: The nature of dormancy responses in insects. Acta Soc. Zool. Bohem. 65: 169-179.

David J.-F., Célérier M.-L. \& Geoffroy J.-J. 1999: Periods of dormancy and cohort-splitting in the millipede Polydesmus angustus (Diplopoda: Polydesmidae). Eur. J. Entomol. 96: 111-116.

Den Boer P.J. \& Van DirK T.S. 1996: Life-history patterns among carabid species. Tijdschr. Entomol. 139: 1-16.

DeWalt R.E. \& Stewart K.W. 1995: Life histories of stoneflies (Plecoptera) in the Rio Conejos of southern Colorado. Gt. Basin Nat. 55: 1-18.

Dixon A.F.G. \& Kundu R. 1998: Resource tracking in aphids: Programmed reproductive strategies anticipate seasonal trends in habitat quality. Oecologia 114: 73-78.

DRANeY M.L. \& CRossley D.A.Jr. 1999: Relationship of habitat age to phenology among ground-dwelling Linyphiidae (Araneae) in the southeastern United States. J. Arachnol. 27: 211-216.

Edgerly J.S. \& LiVDaHL T.P. 1992: Density dependent interactions within a complex life cycle: The roles of cohort structure and mode of recruitment. J. Anim. Ecol. 61: 139-150.

EDGeRly J.S. \& MARVIER M.A. 1992: To hatch or not to hatch? Egg hatch response to larval density and to larval contact in a treehole mosquito. Ecol. Entomol. 17: 28-32.

Ehlert R., Tope W., Thiemermann S. \& Brett B. 1997: Phenotypic plasticity in Choleva agilis to maintain fitness in an unpredictable environment (Coleoptera: Cholevidae). Entomol. Gen. 21: 145-159.

Ellers J. \& Van Alphen J.J.M. 1997: Life history evolution in Asobara tabida: Plasticity in allocation of fat reserves to survival and reproduction. J. Evol. Biol. 10: 771-785.

ERLYKova N.N. 1999: [Effect of photoperiod and maternal age on the progeny sequence of the pea aphid Acyrthosiphon pisum Harris (Homoptera: Aphididae) from the Volga Area]. Entomol. Obozr. 78: 275-286. [in Russian]

EudA T. 1989: Sexual maturation, body colour changes and increase of body weight in a summer diapause population of the damselfly Lestes sponsa (Hansemann) (Zygoptera: Lestidae). Odonatologica 18: 75-87.

Fangsen X. \& Kallenborn H.G. 1998: Control of summer and winter diapause in Pidorus euchromioides (Lepidoptera: Zygaenidae) on Chinese sweetleaf Symplocos chinensis. Bull. Entomol. Res. 88: 207-211.

FISCHER K. \& FIEDLER K. 2000: Sex-related differences in reaction norms in the butterfly Lycaena tityrus (Lepidoptera: Lycaenidae). Oikos 90: 372-380.

FisCHER K. \& FiEDLER K. 2001: Dimorphic growth patterns and sex-specific reaction norms in the butterfly Lycaena hippothoe sumadiensis. J. Evol. Biol. 14: 210-218.

FitzPatrick S.M. \& Troubridge J.T. 1993: Fecundity, number of diapause eggs, and egg size of successive generations of the blackheaded fireworm (Lepidoptera: Tortricidae) on cranberries. Envir. Entomol. 22: 818-823.

Flannagan R.D., Tammariello S.P., Joplin K.H., Cikra-Ireland R.A., Yocum G.D. \& Denlinger D.L. 1998: Diapause-specific gene expression in pupae of the flesh fly Sarcophaga crassipalpis. Proc. Natl. Acad. Sci. USA 95: 5616-5620.

Frank S.A. \& Slatkin M. 1990: Evolution in a variable environment. Am. Nat. 136: 244-260. 
Gaston K.J. \& Reavey D. 1989: Patterns in the life histories and feeding strategies of British macrolepidoptera. Biol. J. Linn. Soc. 37: 367-381.

GebHardt M.D. \& Stearns S.C. 1992: Phenotypic plasticity for life-history traits in Drosophila melanogaster. III. Effect of the environment on genetic parameters. Genet. Res. 60: 87-101

Gerard P.J. \& RUF L.D. 1997: Development and biology of the immature stages of Anthrenocerus australis Hope (Coleoptera: Dermestidae). J. Stored Prod. Res. 33: 347-357.

Gerson E.A., Kelsey R.G. \& Ross D.W. 1999: Pupal diapause of Coloradia pandora Blake (Lepidoptera: Saturniidae). PanPac. Entomol. 75: 170-177.

Giberson D.J. \& RosenberG D.M. 1992a: Effects of temperature, food quantity, and nymphal rearing density on life-history traits of a northern population of Hexagenia (Ephemeroptera: Ephemeridae). J. N. Am. Benthol. Soc. 11: 181-193

Giberson D.J. \& Rosenberg D.M. 1992b: Egg development in Hexagenia limbata (Ephemeroptera:Ephemeridae) from Southern Indian Lake, Manitoba: Temperature effects and diapause. J. N. Am. Benthol. Soc. 11: 194-203.

Giberson D.J. \& Rosenberg D.M. 1994: Life histories of burrowing mayflies (Hexagenia limbata and H. rigida, Ephemeroptera: Ephemeridae) in a northern Canadian reservoir. Freshwat. Biol. 32: 501-518.

Glitho I.A., Lenga A. \& Huignard J. 1991: Intensity of the male reproductive diapause in Bruchidius atrolineatus Pic Coleoptera Bruchidae is affected by induction conditions. Invert. Reprod. Dev. 19: 233-243.

Glitho I.A., Lenga A., Pierre D. \& Huignard J. 1996: Changes in the responsiveness during two phases of diapause termination in Bruchidius atrolineatus Pic (Coleoptera: Bruchidae). $J$ Insect Physiol. 42: 953-960.

GoDDEERIS B.R. 1990: Life cycle characteristics in Tanytarsus sylvaticus (van der Wulp, 1859) (Chironomidae, Diptera) Annls Limnol. 26: 51-64.

Goto M., Sekine Y., Outa H., Huumkura M. \& Suzuri K. 2001 Relationships between cold hardiness and diapause, and between glycerol and free amino acid contents in overwintering larvae of the oriental corn borer, Ostrinia furnacalis. $J$. Insect Physiol. 47: 157-165.

GotTHARD K., Nylin S. \& WiKLund C. 1994: Adaptive variation in growth rate: Life history costs and consequences in the speckled wood butterfly, Pararge aegeria. Oecologia 99: 281-289

Gotthard K., Nylin S. \& Wiklund C. 1999: Seasonal plasticity in two satyrine butterflies: State-dependent decision making in relation to daylength. Oikos 84: 453-462.

Gotthard K., Nylin S. \& WikLund C. 2000: Individual state controls temperature dependence in a butterfly (Lasiommata maera). Proc. R. Soc. Lond., Ser. B: Biol. Sci. 267: 589-593.

Goulson D. 1993: The evolutionary significance of bimodal emergence in the butterfly, Maniola jurtina (Lepidoptera: Satyrinae) (L.). Biol. J. Linn. Soc. 49: 127-139.

Gray D.R., Ravlin F.W. \& Braine J.A. 2001: Diapause in the gypsy moth: A model of inhibition and development. J. Insect Physiol. 47: 173-184.

Greenslade P.J.M. 1983: Adversity selection and the habitat templet. Am. Nat. 122: 352-365.

HADERSPECK W. \& HoFFMANN K.H. 1990: Effects of photoperiod and temperature on development and reproduction of Hydromedion sparsutum (Müller) (Coleoptera: Perimylopidae) from South Georgia (Subantarctic). Oecologia 83: 99-104.
Hairston N.G.Jr. \& De Stasio B.T.Jr. 1988: Rate of evolution slowed by a dormant propagule pool. Nature 336: 239-242.

HANSKI I. 1988: Four kinds of extra long diapause in insects: A review of theory and observations. Ann. Zool. Fenn. 25 $37-53$.

HANSKI I. \& STAHLS G. 1990: Prolonged diapause in fungivorous Pegomya flies. Ecol. Entomol. 15: 241-244.

Helden A.J. \& Dixon A.F.G. 1998: Generation specific life history traits of winged Sitobion avenae. Entomol. Exp. Appl. 88 $163-167$.

HIGAKI M. \& ANDO Y. 1999: Seasonal and altitudinal adaptations in three katydid species: Ecological significance of initial diapause. Entomol. Sci. 2: 1-11.

Hodek I. 1971: Sensitivity to photoperiod in Aelia acuminata (L.) after adult diapause. Oecologia 6: 152-155.

HODEK I. 1979: Intermittent character of adult diapause in Aelia acuminata (Heteroptera). J. Insect Physiol. 25: 867-871.

HoDEK I. 1981: Le rôle des signaux de l'environnement et des processus endogènes dans la régulation de la reproduction par la diapause imaginale. Bull. Soc. Zool. Fr. 106: 317-325.

HODEK I. 1983: Role of environmental factors and endogenous mechanisms in the seasonality of reproduction in insects diapausing as adults. In: Brown V.K. \& Hodek I. (eds): Diapause and Life Cycle Strategies in Insects. Series Entomologica, vol 23. Junk, The Hague, pp. 9-33.

Hodek I. 1999: Environmental regulation and some neglected aspects of insect diapause. Entomol. Sci. 2: 533-537.

Hodek I. \& HodKová M. 1992: Regulation of postdiapause reproduction by recurrent photoperiodic response. In: Bennettová B., Gelbič I. \& Soldán T. (eds): Advances in Regulation of Insect Reproduction. Institute of Entomology, Czech Academy of Sciences, pp. 119-124.

IKEDA-KIKUE K. \& NuMATA H. 1992: Effects of diet, photoperiod and temperature on the postdiapause reproduction in the cabbage bug, Eurydema rugosa. Entomol. Exp. Appl. 64: 31-36.

IKEDA-KIKUE K. \& NuMATA H. 1994: Effect of low temperature on the termination of photoperiodic and food-mediated diapause in the cabbage bug, Eurydema rugosa Motschulsky (Heteroptera: Pentatomidae). Appl. Entomol. Zool. 29: 229-236.

INGRISCH S. 1986: The plurennial life cycles of the European Tettigoniidae (Insecta: Orthoptera). 1. The effect of temperature on embryonic development and hatching. Oecologia 70: 606-616.

InOUE T. \& HARADA T. 1997: Sensitive stages in the photoperiodic determination of wing forms and reproduction in the water strider, Aquarius paludum (Fabricius). Zool. Sci. 14: $21-27$.

Inoue T., Toril S., Nishimura T. \& Wakayama M. 2000: Effects of photoperiod and temperature on reproductive diapause in the camphor tree weevil, Dyscerus hylobioides (Desbrochers) (Coleoptera: Curculionidae). Entomol. Sci. 3: 237-244.

IrIARTE P.F. \& Hasson E. 2000: The role of the use of different host plants in the maintenance of the inversion polymorphism in the cactophilic Drosophila buzzatii. Evolution 54: 1295-1302.

IsHiHARA M. 1999: Adaptive phenotypic plasticity and its difference between univoltine and multivoltine populations in a bruchid beetle, Kytorhinus sharpianus. Evolution 53:1979-1986.

IsHIHARA M. 2000: Effect of variation in photoperiodic response on diapause induction and developmental time in the willow leaf beetle, Plagiodera versicolora. Entomol. Exp. Appl. 96: $27-32$.

IsHiHARA M. \& SHIMADA M. 1994: Causes of reproductive inactivity and recovery of reproductive ability after diapause in 
females of a multivoltine bruchid, Kytorhinus sharpianus (Coleoptera: Bruchidae). Ann. Entomol. Soc. Am. 87: 532-537.

Ітон R. 1994: Life cycle of the collembolan Sminthurus arborealis Itoh, a species active in winter on trees. Acta Zool. Fenn. 195: $87-88$.

JiA F.-Y., Greenfield M.D. \& Collins R.D. 2000: Genetic variance of sexually selected traits in waxmoths: Maintenance by genotype x environment interaction. Evolution 54: 953-967.

JOHNSEN S. \& GUTIERREZ A.P. 1997: Induction and termination of winter diapause in a Californian strain of the cabbage maggot (Diptera: Anthomyiidae). Envir. Entomol. 26: 84-90.

JoHNSEN S., GUTIERREZ A.P. \& JoRGENSEN J. 1997: Overwintering in the cabbage root fly Delia radicum: A dynamic model of temperature-dependent dormancy and post-dormancy development. J. Appl. Ecol. 34: 21-28.

Kalushkov P., Hodková M., NedvĚd O. \& Hodek I. 2001 Effect of thermoperiod on diapause intensity in Pyrrhocoris apterus (Heteroptera: Pyrrhocoridae). J. Insect Physiol. 47: $55-61$.

Kalushrov P. \& Nedvěd O. 2000: Cold hardiness of Pyrrhocoris apterus (Heteroptera: Pyrrhocoridae) from central and southern Europe. Eur. J. Entomol. 97: 149-153.

Kamata N. \& Igarashi M. 1995: Relationship between temperature, number of instars, larval growth, body size, and adult fecundity of Quadricalcarifera punctatella (Lepidoptera: Notodontidae): Cost-benefit relationship. Envir. Entomol. 24 648-656.

KAPLIN V.G. 1995: [Life history of the cockroach Anisogamia tamerlana Sauss. (Blattodea: Corydiidae) in the East Karakum]. Entomol. Obozr. 74: 287-298. [in Russian]

KARLSSON B. 1995: Resource allocation and mating systems in butterflies. Evolution 49: 955-961.

Kaто Y. 1989: Role of photoperiod in larval growth of Sasakia charonda (Lepidoptera: Nymphalidae). Jap. J. Entomol. 57: 221-230.

Kawano S. \& ANDo Y. 1997: Effects of photoperiod on nymphal development, pre-oviposition period and egg diapause in the subtropical rice grasshopper, Oxya chinensis formosana Shiraki (Orthoptera: Catantopidae). Appl. Entomol. Zool. 32: $465-470$

KAWECKI T.J. 1995: Expression of genetic and environmental variation for life history characters on the usual and novel hosts in Callosobruchus maculatus (Coleoptera: Bruchidae). Heredity 75: 70-76.

KeMP D.J. 2000: The basis of life-history plasticity in the tropical butterfly Hypolimnas bolina (L.) (Lepidoptera: Nymphalidae). Aust. J. Zool. 48: 67-78.

KFIR R. 1991: Effect of diapause on development and reproduction of the stem borers Busseola fusca (Lepidoptera: Noctuidae) and Chilo partellus (Lepidoptera: Pyralidae). J. Econ. Entomol. 84: 1677-1680.

KIM S.S., HYuN J.S. \& Boo K.S. 1990: Effects of photoperiod and temperature on the summer diapause of the dark grey cutworm, Agrotis tokionis Butler. Korean J. Appl. Entomol. 29: $123-131$.

KimuRA M.T. 1990: Quantitative response to photoperiod during reproductive diapause in the Drosophila auraria speciescomplex. J. Insect Physiol. 36: 147-152.

KimurA Y. \& MASARI S. 1998: Diapause programming with variable critical daylength under changing photoperiodic conditions in Mamestra brassicae (Lepidoptera: Noctuidae). Entomol. Sci. 1: 467-475.

KindLMAnN P. \& Dixon A.F.G. 1992: Optimum body size: Effects of food quality and temperature, when reproductive growth rate is restricted, with examples from aphids. $J$. Evol. Biol. 5: 677-690.

KipYATKov V.E. 1994: [Role of endogenous rhythms in regulation of annual cycles of development in ants (Hymenoptera, Formicidae)]. Entomol. Obozr. 73: 540-553. [in Russian]

Kleckner C.A., Hawley W.A., Bradshaw W.E., Holzapfel C.M. \& Fisher I.J. 1995: Protandry in Aedes sierrensis: The significance of temporal variation in female fecundity. Ecology 76: 1242-1250.

KLINGENBerG C.P. \& SpenCe J.R. 1997: On the role of body size for life-history evolution. Ecol. Entomol. 22: 55-68.

KNULLLE W. 1991: Genetic and environmental determinants of hypopus duration in the stored-product mite Lepidoglyphus destructor. Exp. Appl. Acarol. 10: 231-258.

Köhler G., Reinhardt K. \& Asshoff R. 1999: Zur Biologie der Tessiner Gebirgsschrecke Miramella formosanta (Frühstorfer, 1921) (Acrididae: Catantopinae). Mitt. Schweiz. Entomol. Ges. 72: 315-328.

Komatsu T. \& Akmoto S. 1995: Genetic differentiation as a result of adaptation to the phenologies of individual host trees in the galling aphid Kaltenbachiella japonica. Ecol. Entomol. 20: $33-42$.

KoOI R.E. \& BRAKEFIELD P.M. 1999: The critical period for wing pattern induction in the polyphenic tropical butterfly Bicyclus anynana (Satyrinae). J. Insect Physiol. 45: 201-212.

KošT’ÁL V. \& HoDeK I. 1997: Photoperiodism and control of summer diapause in the Mediterranean tiger moth Cymbalophora pudica. J. Insect Physiol. 43:767-777.

Košt'Ál V., Shimada K. \& Hayakawa Y. 2000: Induction and development of winter larval diapause in a drosophilid fly, Chymomyza costata. J. Insect Physiol. 46: 417-428.

KošT'ÁL V. \& ŠIMEK P. 2000: Overwintering strategy in Pyrrhocoris apterus (Heteroptera): The relations between life-cycle, chill tolerance and physiological adjustments. J. Insect Physiol. 46: 1321-1329.

Kotaki T., NaKakita H. \& Kuwahara M. 1993: Crowding inhibits pupation in Tribolium freemani (Coleoptera: Tenebrionidae): Effects of isolation and juvenile hormone analogues on development and pupation. Appl. Entomol. Zool. 28: 43-52.

KreBs R.A. \& LoescheKe V. 1999: A genetic analysis of the relationship between life-history variation and heat-shock tolerance in Drosophila buzzatii. Heredity 83: 46-53.

LANDA K. 1992: Seasonal declines in offspring fitness and selection for early reproduction in nymph-overwintering grasshoppers. Evolution 46: 121-135.

LANGER A. \& HANCE T. 2000: Overwintering strategies and cold hardiness of two aphid parasitoid species (Hymenoptera: Braconidae: Aphidiinae). J. Insect Physiol. 46: 671-676.

Launors M., Launors-Luong M.H. \& Lecoe M. 1996: Sécheresse et survie des sauteriaux du Sahel ouest Africain. Secheresse 7: 119-127.

Lavenseau L. \& Hilal A. 1990: Regulation des cycles saisonniers chez la sesamie (Lepidoptère: Noctuidae). In: Ferron P., Missonnier J. \& Mauchamp B. (eds): Régulation des Cycles Saisonniers Chez les Invertébrés. Institut National de la Recherche Agronomique, France (Colloq. INRA 52), pp. 243-246.

LeEs A.D. 1990: Dual photoperiodic timers controlling sex and female morph determination in the pea aphid, Acyrthosiphon pisum. J. Insect Physiol. 36: 585-591.

Li Z., JIA F., HE Z. \& Hou W. 1993: [Effect of photoperiods on larval growth and development of Dendrolimus punctatus. Forest Res. 6: 276-281]. [in Chinese] 
LindegaARD C. \& MÆHL P. 1993: Abundance, population dynamics and production of Chironomidae (Diptera) in an ultraoligotrophic lake in south Greenland. Neth. J. Aquat. Ecol. 26: 297-308.

LogAN J.A. \& BeNTz B.J. 1999: Model analysis of mountain pine beetle (Coleoptera: Scolytidae) seasonality. Envir. Entomol. 28: 924-934.

Mappes J., Kaitala A. \& Rinne V. 1996: Temporal variation in reproductive allocation in a shield bug Elasmostethus interstinctus. J. Zool. 240: 29-35.

MARKov V.A. 1997: [Long-term embryonic diapause and the heterogeneity of Ocneria dispar (Lepidoptera: Lymantriidae) population with respect to term of development]. Entomol. Obozr. 76: 56-80. [in Russian]

Martin T.H., Johnson D.M. \& MoOre R.D. 1991: Fishmediated alternative life-history strategies in the dragonfly Epitheca cynosura. J. N. Am. Benthol. Soc. 10: 271-279.

MARUYAMA T. \& SHINKAлI N. 1991: The life cycle of the box-tree pyralid, Glyphodes perspectalis (Walker) (Lepidoptera: Pyralidae). II. Developmental characteristics of larvae. Jap. J. Appl. Entomol. Zool. 35: 221-230.

MASAKI S. 1996: Geographical variation of life cycle in crickets (Ensifera: Grylloidea). Eur. J. Entomol. 93: 281-302.

MASAKI S. 1999: Seasonal adaptations of insects as revealed by latitudinal diapause clines. Entomol. Sci. 2: 539-549.

MCGREGOR R. 1997: Influence of photoperiod on larval development in the leafmining moth Phyllonorycter mespilella (Lepidoptera: Gracillaridae). Ann. Entomol. Soc. Am. 90: 333-336.

MCLACHLAN A.J. 1986: Sexual dimorphism in midges: Strategies for flight in the rain-pool dweller Chironomus imicola (Diptera: Chironomidae). J. Anim. Ecol. 55: 261-267.

McPeek M.A. \& Peckarsky B.L. 1998: Life histories and the strengths of species interactions: Combining mortality, growth, and fecundity effects. Ecology 79: 867-879.

Menu F. 1993: Strategies of emergence in the chestnut weevil Curculio elephas (Coleoptera: Curculionidae). Oecologia 96: 383-390.

Menu F. \& Debouzie D. 1993: Coin-flipping plasticity and prolonged diapause in insects: Example of the chestnut weevil Curculio elephas (Coleoptera: Curculionidae). Oecologia 93 : $367-373$.

Menu F., Roebuck J.-P. \& Viala M. 2000: Bet-hedging diapause strategies in stochastic environments. Am. Nat. 155: 724-734.

Moreira G.R.P. \& Peckarsky B.L. 1994: Multiple developmental pathways of Agnetina capitata (Plecoptera: Perlidae) in a temperate forest stream. J. N. Am. Benthol. Soc. 13: $19-29$.

Müller H.J. 1970: Formen der Dormanz bei Insekten. Nova Acta Leopoldina 35: 7-27.

Murray A.M. \& Giller P.S. 1991: Life history and overwintering tactics of Velia caprai Tam. (Hemiptera: Veliidae) in southern Ireland. Aquat. Insects 13: 229-243.

Musolin D.L. \& SAutich A.H. 1999: Diversity of seasonal adaptations in terrestrial true bugs (Heteroptera) from the temperate zone. Entomol. Sci. 2: 623-639.

NAKAI T. \& TAKEDA M. 1995: Temperature and photoperiodic regulation of summer diapause and reproduction in Pyrrhalta humeralis (Coleoptera: Chrysomelidae). Appl. Entomol. Zool. 30: 295-301.

NAKAMURA K., Hodek I. \& Hodková M. 1996: Recurrent photoperiodic response in Graphosoma lineatum (Heteroptera: Pentatomidae). Eur. J. Entomol. 93: 519-523.
NaKamuRa K. \& Numata H. 1998: Alternative life cycles controlled by temperature and photoperiod in the oligophagous bug, Dybowskyia reticulata. Physiol. Entomol. 23: 69-74.

Nakamura K. \& Numata H. 2000: Photoperiodic control of the intensity of diapause and diapause development in the bean bug, Riptortus clavatus (Heteroptera: Alydidae). Eur. J. Entomol. 97: 19-23.

Neal J.W.Jr., Chittams J.L. \& Bentz J.-A. 1997: Spring emergence by larvae of the eastern tent caterpillar (Lepidoptera: Lasiocampidae): A hedge against high-risk conditions. Ann. Entomol. Soc. Am. 90: 596-603.

Nealis V.G., Oliver D. \& TchiR D. 1996: The diapause response to photoperiod in Ontario populations of Cotesia melanoscela (Ratzeburg) (Hymenoptera: Braconidae). Can. Entomol. 128: 41-46.

NefF J.L. \& Simpson B.B. 1992: Partial bivoltinism in a groundnesting bee: The biology of Diadasia rinconis in Texas (Hymenoptera, Anthophoridae). J. Kans. Entomol. Soc. 65: 377-392.

Nelemans M.N.E., Den Boer P.J. \& Spee A. 1989: Recruitment and summer diapause in the dynamics of a population of Nebria brevicollis (Coleoptera: Carabidae). Oikos 56: 157-169.

Nicsson A.N. 1986: Life cycles and habitats of the northern European Agabini (Coleoptera: Dytiscidae). Entomol. Basil. 11: 391-417.

Nishimura T. \& Numata H. 1998: Circannual rhythm in pupation of Anthrenus verbasci. Zool. Sci. Suppl. 15: 52.

Nishizuka M., Azuma A. \& Masaki S. 1998: Diapause response to photoperiod and temperature in Lepisma saccharina Linnaeus (Thysanura: Lepismatidae). Entomol. Sci. 1: 7-14.

Niva C.C. \& Becker M. 1998: Embryonic external morphogenesis of Rhammatocerus conspersus (Bruner) (Orthoptera: Acrididae: Gomphocerinae) and determination of the diapausing embryonic stage. An. Soc. Entomol. Bras. 27: $577-583$.

Nolte U., De Oliveira M.J. \& Stur E. 1997: Seasonal, discharge driven patterns of mayfly assemblages in an intermittent neotropical stream. Freshwat. Biol. 37: 333-343.

Nomura M. \& IshiKawa Y. 2000: Biphasic effect of low temperature on completion of winter diapause in the onion maggot, Delia antiqua. J. Insect Physiol. 46: 373-377.

NORTON R.A. 1994: Evolutionary aspects of oribatid mite life histories and consequences for the origin of the Astigmata. In: Houck M.A. (ed.): Mites: Ecological and Evolutionary Analyses of Life-History Patterns. Chapman and Hall, New York, London, pp. 99-135.

NOVAKOVA J. \& NEDVẼD O. 1999: Developmental time and body mass in Pyrrhocoris apterus (Heteroptera: Pyrrhocoridae) under contrasting photo- and thermoperiods. Entomol. Problems 30: 97-100.

Numata H. \& Kobayashi S. 1994: Threshold and quantitative photoperiodic responses exist in an insect. Experientia 50: 969-971.

Nyun S. 1994: Seasonal plasticity and life-cycle adaptations in butterflies. In: Danks H.V. (ed.): Insect Life-Cycle Polymorphism: Theory, Evolution and Ecological Consequences for Seasonality and Diapause Control. Kluwer Academic Publishers, Dordrecht. Series Entomologica 52, pp. 41-67.

Nylin S. \& Gotthard K. 1998: Plasticity in life-history traits. Annu. Rev. Entomol. 43: 63-83.

Nylin S., Wickman P.-O. \& Wiklund C. 1989: Seasonal plasticity in growth and development of the speckled wood butterfly, Pararge aegeria (Satyrinae). Biol. J. Linn. Soc. 38: 155-171. 
Orshan L. \& Pener M.P. 1979: Repeated reversal of the reproductive diapause by photoperiod and temperature in males of the grasshopper, Oedipoda miniata. Entomol. Exp. Appl. 25: 219-226.

PARSONS P.A. 1993: The importance and consequences of stress in living and fossil populations: From life-history variation to evolutionary change. Am. Nat. 142: S5-S20.

Peckarsky B.L., Cowan C.A., Penton M.A. \& Anderson C. 1993: Sublethal consequences of stream-dwelling predatory stoneflies on mayfly growth and fecundity. Ecology 74: $1836-1846$.

Peckarsky B.L., Taylor B.W. McIntosh A.R., McPeek M.A. \& LYTLE D.A. 2001: Variation in mayfly size at metamorphosis as a developmental response to risk of predation. Ecology 82: $740-757$.

Pener M.P. 1997: Endocrine factors and female-male coadaptations in reproductive diapause-related strategies of acridoid insects. In: Gangwere S.K., Muralirangan M.C. \& Muralirangan M. (eds): The Bionomics of Grasshoppers, Katydids and Their Kin. $\mathrm{CAB}$ International, Wallingford, England, pp. 315-336.

Pener M.P. \& Yerushalmi Y. 1998: The physiology of locust phase polymorphism: An update. J. Insect Physiol. 44: 365-377.

PIтT W.C. 1999: Effects of multiple vertebrate predators on grasshopper habitat selection: Trade-offs due to predation risk, foraging, and thermoregulation. Evol. Ecol. 13: 499-515.

Powell J.A. \& JENKINS J.L. 2000: Seasonal temperature alone can synchronize life cycles. Bull. Math. Biol. 62: 977-998.

PrICE P.W. 1994: Phylogenetic constraints, adaptive syndromes, and emergent properties: From individuals to population dynamics. Res. Popul. Ecol. 36: 3-14.

Pritchard G., Harder L.D. \& Mutch R.A. 1996: Development of aquatic insect eggs in relation to temperature and strategies for dealing with different thermal environments. Biol. J. Linn. Soc. 58: 221-244.

Pullin A.S. 1990: Physiological interactions between diapause and cold tolerance in Pieris brassicae. Cryobiology 27: 635-636.

Rasumova A.P. 1995: [Annual rhythms in geographical populations of Hawthorn mite Tetranychus crataegi Hirst (Acarina: Tetranychidae)]. Entomol. Obozr. 74: 227-233 (1996). [in Russian] (Translation in Entomol. Rev. 75(5): 27-32, 1996).

Rochat J., Vanlerberghe-Masutti F., Chavigny P., Boll R. \& LAPCHIN L. 1999: Inter-strain competition and dispersal in aphids: Evidence from a greenhouse study. Ecol. Entomol. 24: $450-464$.

RoFr D.A. 1992: The Evolution of Life Histories; Theory and Analysis. Chapman \& Hall, New York, New York, 535 pp.

Ruberson J.R., Bush L. \& Kring T.J. 1991: Photoperiodic effect on diapause induction and development in the predator Orius insidiosus (Heteroptera: Anthocoridae). Envir. Entomol. 20: $786-789$.

SAIGUSA M. \& AkIYAMA T. 1995: The tidal rhythm of emergence, and the seasonal variation of this synchrony, in an intertidal midge. Biol. Bull. 188: 166-178.

SAKWINSKa O. 1997: Adaptive role of phenotypic plasticity in life history traits. Wiad. Ekolog. 43: 191-205.

SANGPRAdub N., GILler P.S. \& O'CONNOR J.P. 1999: Life history patterns of stream-dwelling caddis. Arch. Hydrobiol. 146 471-493.

SAUNDERS D.S. 1997: Under-sized larvae from short-day adults of the blow fly, Calliphora vicina, side-step the diapause programme. Physiol. Entomol. 22: 249-255.
SAUnders D.S. \& HAYward S.A.L. 1998: Geographical and diapause-related cold tolerance in the blow fly, Calliphora vicina. J. Insect Physiol. 44: 541-551.

SCHAFFER W.M. 1974: Selection for optimal life histories: The effects of age structure. Ecology 55: 291-303.

SchWarzKopf L., Blows M.W. \& Caley M.J. 1999: Life-history consequences of divergent selection on egg size in Drosophila melanogaster. Am. Nat. 154: 333-340.

Sharov A.A. 1993: Biology and population dynamics of common pine sawfly, Diprion pini L., in Russia. In: Wagner M.R. \& Raffa K.F. (eds): Sawfly Life History Adaptations to Woody Plants. Academic Press, San Diego, CA; London, England, pp. 409-429.

Sharova I. Kh. \& Denisova M.I. 1997: [Seasonal dynamics of carabid populations from the genus Pterostichus (Coleoptera: Carabidae)]. Zool. Zh. 76: 418-427. [in Russian]

SHINDO J.-I. \& MASAKI S. 1995: Photoperiodic control of larval development in the semivoltine cockroach Periplaneta japonica (Blattidae: Dictyoptera). Ecol. Res. 10: 1-12.

SHINTANI Y. \& IsHIKAWA Y. 1997: Diapause avoidance induced by low temperature in the yellow-spotted longicorn beetle, Psacothea hilaris. Entomol. Exp. Appl. 85: 11-15.

Shintani Y., IshiKaWA Y. \& TATSUKI S. 1996: Larval diapause in the yellow-spotted longicorn beetle, Psacothea hilaris (Pascoe) (Coleoptera: Cerambycidae). Appl. Entomol. Zool. 31: 489-494.

Singtripop T., Wantchacheewa S., TsuzuKi S. \& Sakurai S. 1999: Larval growth and diapause in a tropical moth, Omphisa fuscidentalis Hampson. Zool. Sci. 16: 725-733.

SoutHwoon T.R.E. 1988: Tactics, strategies and templets. Oikos 52: 3-18.

SPENCE J.R. 2000: Seasonal aspects of flight in water striders (Hemiptera: Gerridae). Entomol. Sci. 3: 399-417.

STADLER B. 1992: Physiological responses of Uroleucon jaceae (L.) to seasonal changes in the quality of its host plant Centaurea jacea L.: Multilevel control of adaptations to the life cycle of the host. Oecologia 91: 273-280.

STADLER B. 1995: Adaptive allocation of resources and life-history trade-offs in aphids relative to plant quality. Oecologia 102: 246-254.

Statzner B., Hoppenhaus K., Arens M.-F. \& Richoux P. 1997: Reproductive traits, habitat use and templet theory: A synthesis of world-wide data on aquatic insects. Freshwat. Biol. 38: 109-135.

Stearns S.C. 1992: The Evolution of Life Histories. Oxford University Press, New York, 249 pp.

STEARNS S.C. \& KaWECKI T.J. 1994: Fitness sensitivity and the canalization of life-history traits. Evolution 48: 1438-1450.

Stockley P. \& Seal N.J. 2001: Plasticity in reproductive effort of male dung flies (Scatophaga stercoraria) as a response to larval density. Funct. Ecol. 15: 96-102.

SUzUKI Y. \& TANAKA S. 2000: Environmental control of nymphal development and diapause in three subtropical populations of a cricket, Modicogryllus confirmatus Walker (Orthoptera: Gryllidae). Entomol. Sci. 3: 571-577.

SVENSSON B.W. 1999: Environmental heterogeneity in space and time: Patch use, recruitment and dynamics of a rock pool population of a gyrinid beetle. Oikos 84: 227-238.

SweEnEy B.W., JaCKSON J.K. \& FunK D.H. 1995: Semivoltinism, seasonal emergence, and adult size variation in a tropical stream mayfly (Euthyplocia hecuba). J. N. Am. Benthol. Soc. 14: 131-146.

Sweeney J. \& Gesner G. 1997: Effect of gibberellic acid $4 / 7$ on cone crop of Picea glauca and prolonged diapause in Strobilomyia neanthracina. In: Battisti A. \& Turgeon J.J. (eds): Pro- 
ceedings of the 5th Cone and Seed Insects Working Party Conference (IUFRO S7.03-01). Institute of Agricultural Entomology, University of Padova, Padova, pp. 141-148.

TAMmaru T. 1998: Determination of adult size in a folivorous moth: Constraints at instar level? Ecol. Entomol. 23: 80-89.

TANAKA K. 1992: Photoperiodic control of diapause and climatic adaptation of the house spider, Achaearanea tepidariorum (Araneae: Theridiidae). Funct. Ecol. 6: 545-552.

TANAKA S. 1994: Diapause as a pivotal factor for latitudinal and seasonal adaptation in Locusta migratoria in Japan. In: Danks H.V. (ed.): Insect Life-Cycle Polymorphism: Theory, Evolution and Ecological Consequences for Seasonality and Diapause Control. Kluwer Academic Publishers, Dordrecht. Series Entomologica 52, pp. 173-190.

TANaKa S. \& Uemura Y. 1996: Flexible life cycle of a cockroach Periplaneta japonica with nymphal diapause. J. Orthoptera Res. 5: 213-219.

TANAKA S., ARAI T. \& TANAKA K. 1999: Nymphal development, diapause and cold-hardiness in a nymph- overwintering cricket. Entomol. Sci. 2: 173-182.

TAsch P. \& TopP W. 1991: Überleben mit Insektivoren: Der Entwicklungzyklus der Kurzflügers Quedius ochripennis Mén. (Col., Staphylinidae). Zool. Jb. Syst. 118: 359-375.

Tauber C.A., De León T., Arroyo J.I.L. \& Tauber M.J. 1998: Ceraeochrysa placita (Neuroptera: Chrysopidae): Generic characteristics of larvae, larval descriptions, and life cycle. Ann. Entomol. Soc. Am. 91: 608-618.

TAYLOR M.F.J. 1988: Field measurement of the dependence of life history on plant nitrogen and temperature for a herbivorous moth. J. Anim. Ecol. 57: 873-892.

Thiele H.U. 1977: Carabid Beetles in Their Environments. Springer-Verlag, Berlin, $369 \mathrm{pp}$.

Thomas R.H. 1993: Ecology of body size in Drosophila buzzatii: Untangling the effects of temperature and nutrition. Ecol. Entomol. 18: 84-90.

Tiemann S.G. \& Arsuffi T.L. 1991: Life history patterns of Trichoptera in four central Texas streams with contrasting temperature and flow regimes. Bull. Ecol. Soc. Am. 72: 268.

Tilley R.J.D. 1996: The complex development of larvae of the Speckled Wood butterfly Pararge aegeria (L.) (Lepidoptera: Satyridae) in southern Britain. Entomol. Gaz. 47: 1-7.

Toda M.J. \& KImura M.T. 1997: Life-history traits related to host selection in mycophagous drosophilids. J. Anim. Ecol. 66: $154-166$

Topp W. 1990: Selection for an optimal monovoltine life cycle in an unpredictable environment. Studies on the beetle Catops nigricans Spence (Col., Catopidae). Oecologia 84: 134-141

Topp W. 1994: Seasonal time partitioning and polymorphism in the developmental cycles of sympatric Staphylinoidea (Coleoptera) living in an unstable environment. In: Danks H.V. (ed.): Insect Life-Cycle Polymorphism: Theory, Evolution and Ecological Consequences for Seasonality and Diapause Control. Kluwer Academic Publishers, Dordrecht. Series Entomologica 52, pp. 277-312.

Towns D.R. 1981: Life histories of benthic invertebrates in a Kauri forest stream in northern New Zealand. Aust. J. Mar. Freshwat. Res. 32: 191-211.

Townsend C.R., Doledec S. \& Scarsbrook M.R. 1997: Species traits in relation to temporal and spatial heterogeneity in streams: A test of habitat templet theory. Freshwat. Biol. 37: 367-387.

Townsend G.D. \& Pritchard G. 1998: Larval growth and development of the stonefly Pteronarcys californica (Insecta: Plecoptera) in the Crowsnest River, Alberta. Can. J. Zool. 76: 2274-2280.
Trimble R.M. 1994: Role of photoperiod and temperature in the induction of overwintering pupal diapause in the spotted tentiform leafminer, Phyllonorycter blancardella. Entomol. Exp. Appl. 72: 25-31.

TsCHnNKeL W.R. 1993: Crowding, maternal age, age at pupation, and life history of Zophobas atratus (Coleoptera: Tenebrionidae). Ann. Entomol. Soc. Am. 86: 278-297.

TzanaKaKis M.E. \& VeERMAN A. 1994: Effect of temperature on the termination of diapause in the univoltine almond seed wasp Eurytoma amygdali. Entomol. Exp. Appl. 70: 27-39.

VAn Houten Y.M., Bruin J. \& Veerman A. 1991: Repeated induction and termination of diapause in the predacious mite, Amblyseius potentillae (Garman) (Phytoseiidae). In: Schuster R. \& Murphy P.W. (eds): The Acari: Reproduction, Development and Life-history Strategies. Chapman and Hall, London, pp. 267-275.

Volney W.J.A. \& LieBhold A.M. 1985: Post-diapause development of sympatric Choristoneura occidentalis and C. retiniana (Lepidoptera: Tortricidae) and their hybrids. Can. Entomol. 117: 1479-1488.

WALKER T.J. 1986: Stochastic polyphenism: Coping with uncertainty. Florida Entomol. 69: 46-62.

WardhaUGH K.G. 1986: Diapause strategies in the Australian plague locust (Chortoicetes terminifera Walker). In: Taylor F. \& Karban R. (eds): The Evolution of Insect Life Cycles. Proceedings in Life Sciences, Springer-Verlag, New York, Berlin, pp. 89-104.

Wassmer G.T. \& PAGe T.L. 1993: Photoperiodic time measurement and a graded response in a cockroach. J. Biol. Rhythms 8: 47-56.

Watanabe M. \& TanaKa K. 2000: Hormonal control of diapause and overwintering traits in a leaf beetle, Aulacophora nigripennis. Physiol. Entomol. 25: 337-345.

Weiss S.B., Murphy D.D., Ehrlich P.R. \& Metzler C.F. 1993: Adult emergence phenology in checkerspot butterflies: The effects of macroclimate, topoclimate, and population history. Oecologia 96: 261-270.

WeIss S.B. \& WeISS A.D. 1998: Landscape-level phenology of a threatened butterfly: A GIS-based modeling approach. Ecosystems 1: 299-309.

WIPKING W. 1995: Influences of daylength and temperature on the period of diapause and its ending process in dormant larvae of burnet moths (Lepidoptera: Zygaenidae). Oecologia 102: 202-210.

Wirking W. \& Mengelikoch C. 1994: Control of alternate-year flight activities in high-alpine Ringlet butterflies (Erebia: Satyridae) and Burnet moths (Zygaena: Zygaenidae) from temperate environments. In: Danks H.V. (ed.): Insect LifeCycle Polymorphism: Theory, Evolution and Ecological Consequences for Seasonality and Diapause Control. Kluwer Academic Publishers, Dordrecht. Series Entomologica 52, pp. 313-347.

Woon D.M., Dang P.T. \& Elurs R.A. 1979: The Mosquitoes of Canada (Diptera: Culicidae). The Insects and Arachnids of Canada, Part 6. Agriculture Canada, Ottawa, 390 pp.

Worland M.R., Block W. \& Grubor-Lajsic G. 2000: Survival of Heleomyza borealis (Diptera: Heleomyzidae) larvae down to $-60^{\circ}$ C. Physiol. Entomol. 25 : 1-5.

Yule C.M. \& Pearson R.G. 1996: Aseasonality of benthic invertebrates in a tropical stream on Bougainville Island, Papua New Guinea. Arch. Hydrobiol. 137: 95-117.

ZASLAVSKI V.A. 1995: Induction and deinduction in insect photoperiodism: Experimental evidence and a model. Eur. J. Entomol. 92: 401-413. 
Zera A.J. \& Denno R.F. 1997: Physiology and ecology of dispersal polymorphism in insects. Annu. Rev. Entomol. 42 207-230.

ZHANG Z.-Q. 1995: Variance and covariance of ovipositional rates and developmental rates in the Phytoseiidae (Acari Mesostigmata): A phylogenetic consideration. Exp. Appl. Acarol. 19: 139-146.
ZonNeveld C. 1996: Being big or emerging early? Polyandry and the trade-off between size and emergence in male butterflies. Am. Nat. 147: 946-965.

ZwICK P. 1996: Variable egg development of Dinocras spp. (Plecoptera: Perlidae) and the stonefly seed bank theory. Freshwat. Biol. 35: 81-100.

Received November 15, 2001; revised January 10, 2002, accepted January 10, 2002 